\title{
The Internationalization of the Graphic Communication Industry in Colombia: The Guild's Springboard Effect
}

\author{
Aura Uribe Arévalo \\ Facultad de Ciencias Económicas y Empresariales, Universidad de Valladolid \\ Avda. Valle Esgueva 6, Valladolid 47011, Spain \\ Tel: 34-983-183-813 E-mail: uribea@hotmail.com \\ María del Valle Santos Alvarez \\ Facultad de Ciencias Económicas y Empresariales, Universidad de Valladolid \\ Avda. Valle Esgueva 6, Valladolid 47011, Spain \\ Tel: 34-983-183-813Ｅ-mail: mvalle@eco.uva.es \\ María Teresa Garcia Merino \\ Facultad de Ciencias Económicas y Empresariales, Universidad de Valladolid \\ Avda. Valle Esgueva 6, Valladolid 47011, Spain \\ Tel: 34-983-183-813 E-mail: temerino@eco.uva.es
}

$\begin{array}{ll}\text { Received: November 4, } 2011 & \text { Accepted: December 22, } 2011 \quad \text { Published: February 16, } 2012 \\ \text { doi:10.5539/ijbm.v7n4p172 } & \text { URL: http://dx.doi.org/10.5539/ijbm.v7n4p172 }\end{array}$

\begin{abstract}
The internationalization of companies has been defined through different approaches as the choice of starting procedures, the management perspective or export subsidies. The latter refers to the support and assistance that public entities and organizations give to companies in order to start their internationalization process.

This research seeks a different perspective in terms of springboard viewpoint as well as the continuity Pla-Barber, Camps-Torres, and Madhok's proposal (2009). It suggests an analysis of the guild's role in the Graphic Communication Industry in Colombia and its effect as a springboard, which facilitates the internationalization of its affiliates through supporting programmes and export promotions.
\end{abstract}

Keywords: Internationalization, Springboard effect, Support plans

\section{The Internationalization Process in Evolution}

Internationalization is an economic-business phenomenon widely studied. It is one of the greatest challenges that a company must deal with in order to survive in a complex and increasing global environment (Acedo, Casillas \& Moreno; 2008). It is the relationship between business and international markets by means of defined, but variable strategies, depending on the context, the capital, and managerial decisions, among other factors.

Internationalization, which is one of the most widespread and important forces, has changed the competitive business environment, allowing new competitors to share the local markets and creating new business opportunities for small and large companies (Grant, 2004).

In adition, internationalization through a gradual interest of companies in foreign markets has brought greater marketing awareness, uncertainty, and risk reduction. This clearly shows why the internationalization phenomenon is seen as a stepwise process (Moen \& Servais, 2002), and why it may be regarded as a very broad one, due to the high variety of mechanisms available to firms to select foreign markets and to enter into them (Coviello \& McAuley, 1999).

The explanation of the internationalization phenomenon in stages is enshrined in the extension and classical model of Uppsala (Johanson \& Vahlne, 1977), where learning prevais (Bilkey \& Tesar, 1977). 
On the other hand, considering the process of internationalization as a gradual process, any company that has achieved it should not be allowed to develop other types of strategies for enhancing its overseas presence. Researchers in strategic management, international entrepreneurship and business have been interested in the phenomenon of globalization lately (Lu \& Beamish, 2001).

Not only big companies can enter to new markets. The growth of international business and market globalization let large companies penetrate foreign markets and SMEs (Canals, 1991).

New trends in research have revealed the existence of new companies that are created with an international focus, known as Born-Globals, beating the gradual export tradition. The cognitive approach helps understand this new business reality (Zahara; et alt; 2005, Acedo \& Jones, 2007).

The internationalization of SMEs is related to the search for new opportunities and challenges of growth that allow adaptation to the environment through the implementation of development and growth stategies. The active participation of the government, guilds, associations and organizations to support a greater share in foreign markets is essential due to the fact that SMEs are the business with extraordinary dynamism and concentration of employment in a country (Calderón \& Fayos, 2004).

SMEs have had an impressive development in the international scene as well as an increasingly active role in foreign markets during the last few years. So, they are expected to take the leading role because of the strength of the global economy, barriers reduction and technological advances (Lu \& Beamish, 2001).

From another line of research, internationalization of companies might be seen from an institutional theory point o view and the concept of isomorphism, where internationalization is given by imitation. It means that the companies reach well balance and blending in when imitating competitor's practices and structures (DiMaggio \& Powell, 1983).

The risk of being the first ones to explore an unknown field can be minimized when markets have already been explored or imitated by other companies. And it can be possible if these start business in similar countries as their competitors do.

\subsection{The Springboard Effect in the Internationalization}

The increase in the global economy makes companies to be present in foreign markets and it implies that governments develop policies to increase competitiveness overseas (Alonso \& Donoso; 1996).

Although competitiveness corresponds to companies or productive sectors, since they export or import goods, innovate products and create jobs, countries play an important role in determining international competitiveness, in terms of their ability to produce and sell goods in international markets, and to increase or maintain their export quotas (Canals, 1991).

In that regard, governments have two missions to foster international competitiveness:

a) To guarantee economic and social stability, so the environment lets continuous improvement to companies, as it's expected.

b) To promote the development of competitive advantages.

To this end, export promotion plans are designed, such as creating the appropiate infrastructure and favorable environment for all companies to participate and be more internationally competitive (Calderón \& Fayos, 2004).

Some researchers question the effectiveness of this type of support because of its inefficiency and lack of results. However, companies need this support since they attempt to open new markets, and their ultimate goal of promoting exports is to contribute to economic development, and increase the living standards in a country (Alonso \& Donoso, 1996). When plans are effective, more companies are willing to use these support services (Diamantapoulos, et al; 1993).

Having in mind this trend of company internationalization, it is interesting to review the strategy used by new emerging multinationals. They use international expansion as a springboard to acquire strategic resources and reduce market and institutional limitations in their country of origin. In this way, these companies overcome disadvantages in the global scenario and make up for their competitive weaknesses (Luo \& Tungg, 2007)

This way of internationalization is common in countries with emerging economies such as China, India, Russia, Brazil, and Mexico, where there is a high number of mergers and acquisitions, and the springboard strategy is considered as an extension of the traditional theories of internationalization theories (Luo \& Tungg, 2007).

Companies with this kind of emerging economies have had the benefit of international companies from developed countries come to their land through cooperation, alliances, and joint venture. (Luo \& Tungg, 2007, 
Guillen and Gracía; 2009) Organizational skills and technology have been transfered, as a consequence, competitive advantages have been expanded, and they have been focused on low cost production. Companies in these emerging markets may become internationalized through some of these traditional ways (Sun, 2009).

Bearing in mind the concept of springboard, as a platform that facilitates the internationalization of companies, the concepts of "Springboard Country" and "Springboard Subsidiary" defined by Pla-Barber, Camps-Torres, and Madhok in 2009 are remarkable, giving a new look at the concepts of the international theory. The authors are based on the trade relations between Spain and Latin America because of tradition and history.

The new multinationals from emerging countries have made great strides in the global economy, e.g Chinese companies have firmly entered to the world markets not only as exporters, but also as foreign investors (Guillén \& García, 2009).

Establishing new markets means learning about the target market and overcoming what has been called psychic distance (Johanson \& Vahlne,1977), the distance exists not only in the physical sense, but also encompasses cultural, institutional, and economic factors, (Hutzschenreuter et. al., 2009). From this view, the concept "springboard country" is thought as the simplest way to get to a country beyond any differences. That is to say, the way to accelerate the internationalization process (Pla-Barber \& Camps-Torres, 2009).

Companies stand to benefit from entering to different institutional settings apart from their country of origin by means of the "springboard country" (Pla-Barber, Camps-Torres, Madhok, 2009). In most cases, managers of companies are afraid of risk. They first choose those countries where knowledge is little, so that they invest there for the first time. Once the company has done business in a country, the managers learn to operate abroad, compete in the industry, and learn how to manage a multinational company (Cuervo, 2008). This learning enables the company to continue its internationalization and settle in countries where information was too little.

Some risks of this springboard strategy are associated to the ack of transparency in emerging markets, which may be political or legal, and likely result in bad business relationships (Luo \& Tungg; 2007). Other difficulties have to do with cultural barriers, integration operations, lack of product innovation, and technology transfer.

To this point, there is a need to evaluate the springboard role that guilds perform to promote the export promotion.

\subsection{Internationalization from a Cognitive View}

The most recent currents have been focused on the role of the manager when deciding internationalization and how they can qualify their action from the cognitive perspective.

One of the central issues in the study of globalization is the position of the manager and the factors that influence those decisions related to internationalization. New researchers have approached to models that have addressed the role of the manager and and his/her influence in decision making (Hambrick \& Mason, 1984; Schwenk, 1988; Wieresma \& Bantel, 1992). In some cases, demographic factors of the managers have been more relevant than cognitive profiles (Hambrick \& Mason, 1984). Cognition refers to the way people think, reason, make decisions,speak, use symbols, and store information for future use (Acedo \& Florin, 2006) (Barón, 1998).

However, from the cognitive perspective, the manager's cognitive variables allow the manager to look for the managerial decisions linked to the internationalization. The growing influence of the cognitive approach in the study of companies' internationalization emphasizes its interest in mental processes and the analysis of individual cognitions as a way to study decision-making (Santos \& García, 2006). In other words, its perceptions about the environment when making decisions and setting strategies (Jiménez \& Martínez, 2004).

Success in internationalization is also granted by the relationships between managers and other actors, such as guilds, associations, and goverments (Claver \& Quer; 2001).

According to the manager's cognitive process, the aim is to identify why some companies begin to export and not others. (Burton \& Schlegelmilch; 1987)

From this viewpoint, the perception of the environment is important at the moment of making the decision to internationalize. Integration models of political, organizational, and cognitive perspective arise in order to analize decision making, but new researchs suggest that demographic factors, personality, and psychological characteristics must be considered (Clarke \& Mckaness 2001; Hambrick \& Mason, 1984).

\section{Internationalization in Colombia: Learning Construction}

Expanding the borders and searching new markets are part of international development strategies in Latin America and specifically in Colombia. So the objective is to be part of the demanding and globalized world 
which politics, relations, and business center on.

There are two remarkable stages in the development of internationalization in Colombia. The first is the import substitution before the 90 's, where domestic production was the central theme of the economy. There was state protection to domestic production, and some regions managed to develop themselves, faster than others. Colombian businessmen focused their business only on domestic markets and did nothing to innovate.

At the early nineties, Colombia and other countries in the region adopted a development model based on establishing and regulating new markets, as well as free market competition. They aimed to have higher levels of economic growth and a better position in the globalization process (Garay, 1998). There was a change towards the internationalization of the economy, leading to a change in Colombian business strategies, a rethink of long-term projections and plans (Castro, 2009).

The economic opening offered the consumer the choice between foreign and domestic goods, the employer faced new competitors, and companies had to look for new markets, which demanded an industrial restructuring (Llinas, 1997). A higher effort in export was necessary for the internationalization to become sustainable (Garay, 1998).

Reviewing institutional theory can be done to bring theory to the way Colombian companies penetrate international markets (DiMaggio \& Powell, 1983). Pressure in the environment leads companies to take actions under isomorphism and the well recognized practice imitation.

Internationalization in Colombia has been remarked by foreign investment - IDE; mergers of domestic companies with foreign companies and franchise schemes (Castro, 2009).

The internationalization strategy requires an export base diversification, training in human resources, communications and infrastructure modernization, improvements in environmental conditions, especially those related to security and drug trafficking, and the development of an attitude towards learning and institutional modernization.

The SMEs participation in exports has been low, because of the obstacles they may face at the time of entering international markets, as the procedures for exporting, inland transportation, limited access to resources as well as a short-term vision. These all limit the results of the export activity.

\subsection{The Graphic Communication Industry: A sector in Evolution}

The guilds represent private sectors. They have existed in Colombia for more than two centuries. They were born thanks to agriculturers. This sector has traditionally been the basis of the Colombian economy.

For Graphic Communication Industry, they are represented by the "Asociación Colombiana de la Industria de la Comunicación Gráfica"-Andigraf-, founded in 1975. It supports graphic companies in their development so that they can achieve optimal levels of performance in all possible markets, nationally and internationally. It also seeks to carry on strategic alliances doing research, analysis, and interchanging information.

The industry has taken advantage of trade agreements, the ones that have already been negotiated (Chile, North Triangle, Mercosur and Mexico) and the ones that are fothcoming (Canada, EFTA and the EU), keeping in mind the approval of the FTA with the US. These markets mean diversification possibilities in the demand and opportunities for the importation of capital goods, inputs, and raw materials, at more competitive prices.

The industry of graphic comunication in Colombia is increasingly prepared to face the world market thanks to its print quality at competitive prices and managers' competence. Also the country's geographical location favors delivery times.

The companies' achievements in the guilds internationalization have been very important for the Industry and Commerce Ministry. In the year 2009, the guild was included in the competitiveness and productivity improvement programme through the definition of class sectors world for its achievements and projections, placing the guild in a strategic position to enter new markets.

The guild strengthens its affiliates with competitiveness agreements, negotiation of comercial agreements and participation in the design of business plans on the table of government, and in the definition of aid schemes for internationalization.

The actors and actions involved in the definition of internationalization strategies of companies in the guild are described in Figure 1.

\subsection{The Effect Springboard of the Guild}

To determine the role springboard of the guild, this paper builds on the interpretation of the reports "Memorias 
Andigraf" and "Boletín Andigraf". It is a retrospective literature review that makes evident the strategy of the guild. It is important to note that the trajectory of the guild in export is product of the experience of its companies associated in foreign markets.

We support on the validation that the content analysis can reach (Andreu, 2001) to interpret and analyze the information document provided by the guild.

The challenges faced by companies of graphic industry in Colombia make Andigraf constantly look for more and better ways to support the development of the sector. For this reason, the Guild made a covenant with Proexport to provide information, training, tools, and coaching to entrepreneurs interested in expanding their graphic supply to international markets.

Andigraf, in coordination with the Centro de Desarrollo Tecnológico para la Competitividad de la Industria de la Comunicación Gráfica-Cigraf-, accompanies in issues related to quality certification, environmental management, technological and process improvement, innovation, and research.

In synthesis, guild challenges are aimed at promoting the internationalization of the Industry of Graphic Communication through improvement programs, management, and productivity. Also, they look for direct intervention of enterprises participating in the implementation of plans aimed at promoting exports of high added value sector, through the strengthening of strategic alliances as a mechanism of internationalization technology for developing centers, universities, research centers, and/or specializing in the management.

The guild has a "springboard" effect to the various challenges that are presented to companies of the sector, in this case to the globalization of markets and enterprise internationalization, as follows:

- In the first phase (1996-1999), its actions are focused on negotiating with the government in international agreements. That is, its function focuses on representing the interests of industry after signing trade agreements with international markets. We could then say that their function is mainly "visible head" of the sector in the negotiation and signing of agreements.

- From year 2000, a new phase in which the function of representing the guild to sign trade agreements for the country, combined with other functions aimed more directly at the companies network of the sector. For example, in 2001, the guild, participated in designing the export plan of the industry and in 2003, in the program PEX, Spanish acronym for Special Export Program. Also, in 2002 directed the study and identification of target markets and in 2004 participated in partnerships with consulting firms of customs and taxes that provide both administrative procedures associated to departure abroad. That means that at this stage, it was more directly involved in the process of internationalization of companies in the guild, facilitating the identification of attractive markets, and reducing the obstacles involved in internationalization.

- The results of total exports of the sector show growth and strength in its international activity (Table 1). The articulation of the actions of industry and government was important to be considered a strategic sector for Colombian international trade.

Cigraf has directed his actions to the training of entrepreneurs, with the aim of creating a business base with sufficient training to enable an effective business management. It is possible to ensure that the business can meet the challenges of the competitive environment, including the internationalization of the sector in better way.

Regarding the evolution of the actions of the guild, these have been of big impact. In 2009, the guild made 13 of 18 actions for the sector, being this the result of the dynamics of the guild towards the internationalization of the sector (Table 2).

\section{Conclusions}

Overpassing the uncertainty caused by Colombia during the 90's makes the whole internationalization action become a challenge for companies, entrepreneurs, and the country. In the case of the guild of graphic communication, building trust is a process that has started to deliver results since 2000 .

The guild of graphic communication by size (number of affiliates) background and experience of each of the companies makes it gain a preferred position along with other guilds.

It can be concluded that the actions of Andigraf and Cigraf are complementary to promote internationalization for companies of Graphic Industry. So, while Cigraf is mostly improving the professionalization of business management, Andigraf has traditionally being negotiated treaties and trade agreements with different countries. In addition, since 2000, concrete actions have been designed in order to intervene directly in the design of the internationalization strategy of Graphic Industry companies. Andigraf could say that acts as a liaison between the 
interests of the industry and the actions of the government, facilitating the internationalization of the entire sector. More recently, it aimed at actions that facilitate the international expansion of each of the companies.

\section{Future Researchs}

This research is the first exploration of the internationalization of Industry of Graphic Comunication in Colombia. It is proposed for future research from the perspective of management and guidance that has the Guild has as a springboard in internationalization, as well as the cognitive perspective of management and its role and vision in the internationalization of the company.

\section{Acknowledgements}

The authors wish to acknowledge the support of the research project (SEJ 2007-0922/ECO) of the Spanish Ministry of Education and Science. We also thank the Fundación Carolina of Spain. We also appreciate the information and collaboration of Cigraf and Andigraf; and Politecnico Grancolombiano.

\section{References}

Acedo, F., Casillas, J., \& Moreno, A. (2008). La internacionalización de la empresa familiar: un análisis exploratorio. Management International, 12(3), 77-122.

Acedo, F. J., \& Florin, J. (2006). An entrepreneurial cognition perspective on the internationalization of SMEs. Journal of International Entrepreneurship, 4(1), 49-67. http://dx.doi.org/10.1007/s10843-006-0482-9

Acedo, F. J., \& Jones, M. (2007). Speed of Internationalization and Entrepreneurial Cognition: Insights and a Comparison between International New Ventures Exporters and Domestic Firms. Journal of world Business, 42, 236-252. http://dx.doi.org/10.1016/j.jwb.2007.04.012

Alonso, J. A., \& Donoso, V. (1996). Obstáculos a la internacionalizacióny políticas públicas de promoción. El caso de España. Papeles de Economía Española, 66, 124-143.

ANDIGRAF. Boletín: Años 2002 - 2009.

ANDIGRAF. Memorias:Años 1996 - 2009.

Andréu, J. (2001). Las técnica de Análisis de Contenido: Una revisión actualizada. [Online] Available: $\mathrm{http}: / /$ public.centrodeestudiosandaluces.es/pdfs/S200103.pdf

Baron, R. A. (1998). Cognitive Mechanisms in Entrepreneurship: Why and When Enterpreneurs Think Differently than Other People?. Journal of Business Venturing, 3, 275-294. http://dx.doi.org/10.1016/S0883-9026(97)00031-1

Bilkey, W., \& Tesar, W. (1977). The Export Behavior of Smaller-Sized Wisconsin Manufacturing Firms. Journal of International Business Studies, 8(1), 93-98. http://dx.doi.org/10.1057/palgrave.jibs.8490783

Burton, F. N., \& Schlegelmilch, B. B. (1987). Profile Analyses of Non-Exporters versus Exporters Grouped by Export Involvement. Management International Review, 27(1), 38-49.

Calderon, H., \& Fayos, T. (2004). Factores empresariales que influyen en las políticas de promoción de las exportaciones: Aplicación a la comunidad valenciana. Dirección y Organización, 30, 122-133.

Calderon, H., \& Fayos, T. (2002). La medición de los resultados de la promoción de las exportaciones dificultad y necesidad. Boletín Económico del ICE, 2746, 35-41.

Canals, J. (1991). Competitividad Internacional y Estrategia de la Empresa. Barcelona:Editorial Ariel S.A.

Castro, A. M. (2009). Aproximación al proceso de internacionalización de las empresas. el caso colombiano. Documento de Investigación No. 55, Universidad del Rosario(ISSN: 0124-8219).

Clarke, I., \& Mackaness, W. (2001). Management Intuition: An interpretative Account of Structure and Content of Decision Schemas Using Cognitive Maps. Journal of Management Studies, 38(2), 147-172. http://dx.doi.org/10.1111/1467-6486.00232

Claver, E., \& Quer, D. (2001). La Dirección Estratégica de la Internacionalización de la empresa: propuestas de un marco teórico integrador. Información Comercial Española, ICE: Revista de Economía, 794, 37-60.

Coviello, N., \& Mcauley, A. (1999). Internationalisation and the Smaller Firm: A review of Contemporary Empirical Research. Management International Review, 39(3), 223-256.

Cuervo, A. (2008). Las distancias en el proceso de internacionalización: el caso del Banco Santander. Universia Business Review, 96-111. 
Diamantopoulos, A., Scheleglmilch, B., \& Tse, K. (1993). Understanding the Role of Export Marketing Assistance: Empirical Evidence and Research Needs. European Jornal of Marketing, 27(4), 5-14. http://dx.doi.org/10.1108/03090569310038085

Dimaggio, P. J., \& Powell, W. W. (1983). The Iron Cage Revisited: Institutional Isomorphism and Collective Rationality in Organizational Fields. American Sociological Review, 48(2), 147-160. http://dx.doi.org/10.2307/2095101

Garay, L. J. (1998). Colombia: Estructura Industrial e Internacionalización 1967 - 1996. Departamento Nacional de Planeación ( ISBN: 958-8025-14-1).

Grant, R. M (2004). Dirección Estratégica, conceptos, técnicas y aplicaciones. Thomson, $4^{\text {a }}$ Edición.

Guillen, M., \& Garcia-Canal, E. (2009). The American Model of the Multinational Firm and the "New" Multinationals from Emerging Economies. Academy of Management Perspectives, 23(2), 23-35.

Hambrick, D., \& Mason, P. (1984). Upper Echelons: The Organization as a Reflection of Its Top Manager's. Academy of Management Review, 9(2), 193-206.

Hutzschenreuter, T., Daveni, R., \& Voll, J. (2009). Temporal and Geographical Patterns of InternationalizationAn Exploratory Analysis. Multinational Business Review, 17(4), 45-75. http://dx.doi.org/10.1108/1525383X200900027

Jimenez, J., \& Martinez, F. (2004). Una revisión de las aportaciones de la escuela cognitiva a la Dirección Estratégica. Revista Europea de Dirección y Economía de la Empresa, 13(2), 43-60.

Johanson, J., \& Vahlne, J. (1977). The Internationalization Process of the Firm - A model of Knowledge Development and Increasing Foreing Market Commitments. Journal of International Business Studies, 8, 23- 32. http://dx.doi.org/10.1057/palgrave.jibs. 8490676

Llinas, F. (1997). Competitividad internacional y estratégica de las empresas colombianas. Gestión, 3, 1-23.

Lu, S. W., \& Beamish, P. W. (2001). The Internationalization and Performance of SMEs. Strategic Management Journal, 22, 565-586. http://dx.doi.org/10.1002/smj.184

Luo, Y., \& Tungg, R. (2007). International Expansion of Emerging Market Enterprises: A Springboard Perspective. Journal of International Business Studies, 38, 481-498. http://dx.doi.org/10.1057/palgrave.jibs. 8400275

Moen, Ø., \& Servais, P. (2002). Born Global or Gradual Global? Examining the Export Behavior of Small and Medium-Sized Enterprises. Journal of International Marketing, 10(3), 49-72. http://dx.doi.org/10.1509/jimk.10.3.49.19540

Pla-Barber, J., Camps-Torres, J., \& Madhok, A. (2009). "País trampolín” y "Filial Trampolín”: una nueva perspectiva en la internacionalización hacia latinoamerica. GCG Georgetown university-Universia, 3(2), 16-28.

Santos, V., \& Garcia, T. (2006). Organizational Change: The Role of Managers' Mental Models". Journal of Change Management, 6(3), 305-320.

Schwenk, C. (1988). The Cognitive Perspective on Strategic Decision Making. Journal of Management, 25(1), 41-55.

Sun, L. S. (2009). Internationalization Strategy of MNEs from Emerging Economies: The Case of Huawei. Multinational Business Review, 17(2), 129 - 135. http://dx.doi.org/10.1108/1525383X200900013

Wiersema, M., \& Bantel, K. (1992). Top Management Team Demography and Corporate Strategic Change. Academy of Management Journal, 35(1), 91-12. http://dx.doi.org/10.2307/256474

Zahara, S. A., Korri, J. S., \& Yu, J. (2005). Cognition and International Entrepreneurship: Implications for Research on International Opportunity Recognition and Exploitation. International Business Review, 14, 129-146. http://dx.doi.org/10.1016/j.ibusrev.2004.04.005 
Table 1. Total Exports of the sector (Mill/ U\$-FOB)

\begin{tabular}{|c|c|}
\hline Año & Vr. \\
\hline 2002 & 73 \\
\hline 2003 & 70 \\
\hline 2004 & 82 \\
\hline 2005 & 93 \\
\hline 2006 & 96 \\
\hline 2007 & 115 \\
\hline 2008 & 104 \\
\hline 2009 & 86 \\
\hline$* 2010$ & 32 \\
\hline $\begin{array}{l}\text { * May - 2010 } \\
\text { Proexport , 2010 }\end{array}$ \\
\hline
\end{tabular}

Table 2. Actions for the Internationalitation of the sector/by year

\begin{tabular}{|c|c|c|c|}
\hline Año & $\begin{array}{c}\text { Actions of guild } \\
\text { (Andigraf + Cigraf) }\end{array}$ & $\begin{array}{c}\text { Actions Sectors: } \\
\text { Goverment + Private }\end{array}$ & Total Actions \\
\hline 2000 & 6 & 4 & 10 \\
\hline 2001 & 8 & 6 & 14 \\
\hline 2002 & 5 & 4 & 9 \\
\hline 2003 & 4 & 4 & 8 \\
\hline 2004 & 7 & 4 & 11 \\
\hline 2005 & 3 & 3 & 6 \\
\hline 2006 & 3 & 2 & 13 \\
\hline 2007 & 8 & 5 & 11 \\
\hline 2008 & 8 & 3 & 18 \\
\hline 2009 & 13 & 5 & \\
\hline The Authors; 2010 &
\end{tabular}




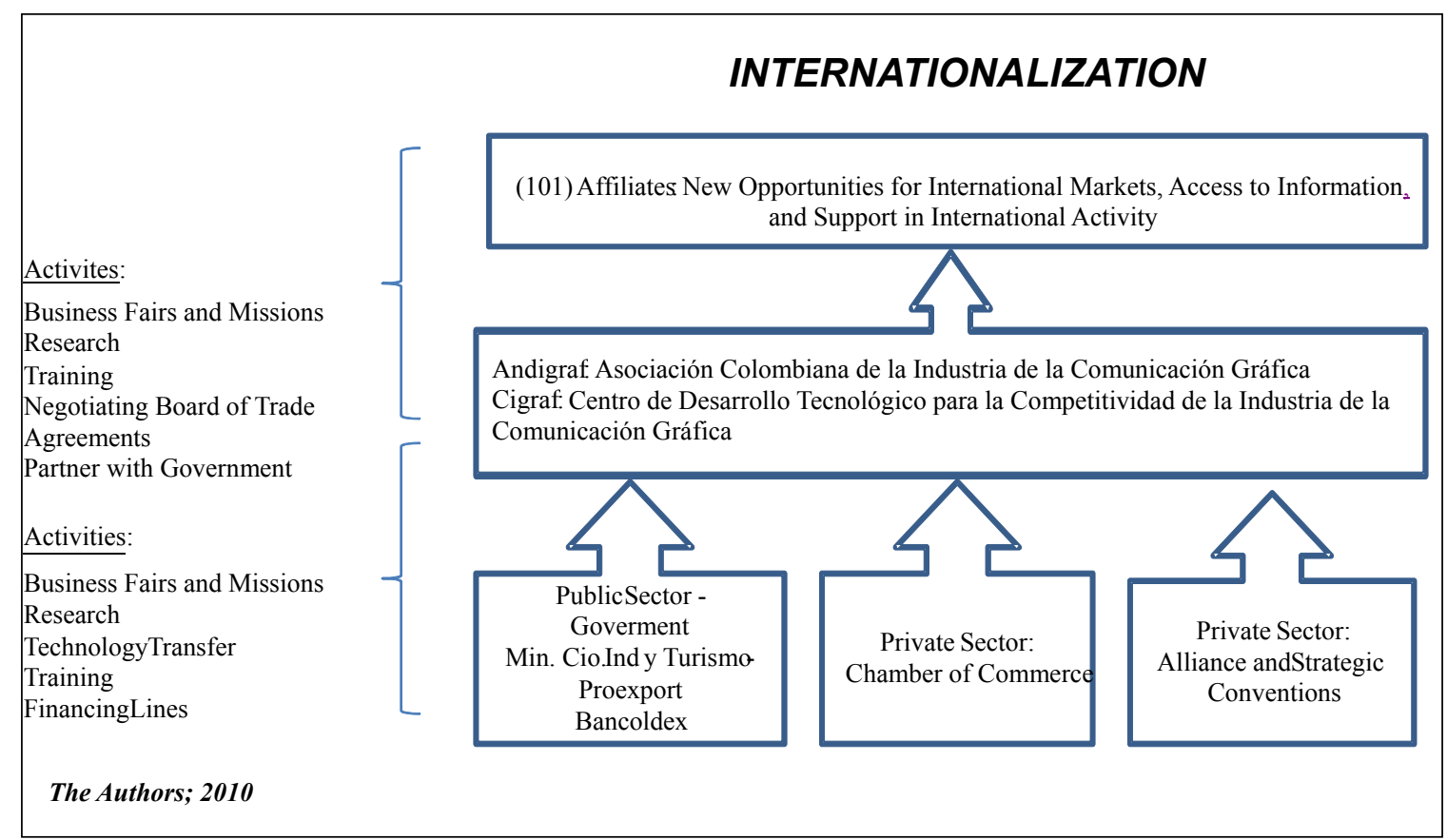

Figure 1. The Guild's Springboard Effect in the Graphic Communication Industry in Colombia 